\title{
FIRST RECORDS OF THE TERRESTRIAL SLUG ARION ATER S. L. (LINNAEUS, 1758) (PULMONATA: ARIONIDAE) FROM TURKEY
}

\author{
Heike Reise ${ }^{*}$, ZEYNEL ARSLANGÜNDOĞDU ${ }^{2}$, BeTtina SCHLITT ${ }^{1}$, JOHN M. C. HUTCHINSON ${ }^{1}$, \\ ERDEM HIZAL ${ }^{2}$, ERGÜN BACAK ${ }^{3}$
}

\begin{abstract}
${ }^{1}$ Senckenberg Museum of Natural History Görlitz, Am Museum 1, 02826 Görlitz, Germany (e-mail: Heike.Reise@senckenberg.de, Bettina.Schlitt@senckenberg.de, majmch@googlemail.com, John.Hutchinson@senckenberg.de)

${ }^{2}$ Istanbul University Cerrahpasa, Forestry Faculty, Department of Forest Entomology and Protection, 34473 Bahçeköy, Istanbul, Turkey (e-mail: zeynel@istanbul.edu.tr, hizal@istanbul.edu.tr) ${ }^{3}$ Istanbul University Cerrahpasa, Vocational High School of Forestry, Forestry Department, 34473 Bahçeköy, Istanbul, Turkey (e-mail: ergun.bacak@istanbul.edu.tr)

*corresponding author
\end{abstract}

\begin{abstract}
A strong population of the terrestrial slug Arion ater s. 1. is reported from the European and Asian parts of Istanbul, Turkey. This is the first confirmed report of this large, conspicuous taxon from Turkey and from Asia. Our samples from five synanthropic sites indicate that it is already well established. Partial sequences of the mitochondrial COI gene (cytochrome c oxidase subunit I) place the Turkish slugs in a small clade shared with a few specimens from western France, perhaps indicating the origin of the Istanbul population. The next closest haplotypes (9\% difference) fall within the clade identified as Arion ater s. s. This fits with the genital morphology of the Turkish slugs, which is most similar to the ater-form of $A$. ater s. l. Our discovery also puts a new light on the recent report of the highly invasive pest slug Arion lusitanicus auct. non Mabille, 1868 (often called Arion vulgaris Moquin-Tandon, 1855) in Isparta, which was identified only on the basis of external morphology. As reliable morphological distinction of these two species requires examination of the genital anatomy, the specimen from Isparta should be reinvestigated.
\end{abstract}

KEY WORDS: invasive species, Arion lusitanicus, Arion vulgaris, Arion rufus, Istanbul

\section{INTRODUCTION}

Some synanthropic species of terrestrial molluscs are prone to spread: they hide under items such as bricks, plastic sheets and wood piled up in the open before being transported elsewhere, or they live on horticultural plants or vegetables. Young slugs or eggs may be transported in the soil of flower pots. An ability to self-fertilise may help single displaced specimens to establish a new population. But in any case, most terrestrial molluscs are hermaphrodites, so every adult that had mated prior to its dispersal may lay fertilised eggs, and every other mature conspecific encountered is a potential mate.

A particularly notorious case is the highly invasive Arion lusitanicus auct. non Mabille, 1868 (henceforth called just $A$. lusitanicus), also often called $A$. vulgaris Moquin-Tandon, 1855 (nomenclature currently under consideration by the ICZN: BALASHOV 2018). This large slug has a considerable potential as an agricultural and horticultural pest. It has spread across Western and Central Europe and into Northern and Eastern Europe, and it has recently also turned up in North America (HATTELAND et al. 2013, PĂPUREANU et al. 2014 and references therein, ZEMANOVA et al. 2016, 2018). So, it was not too surprising that $A$. lusitanicus was recently reported from Turkey (as $A$. vulgaris, YILDIRIM \& GÜRLEK 2017). The nearest earlier records are from Bulgaria, only 440-500 km away (see PĂPUREANU et al. 2014). 
However, A. lusitanicus is not the only large Arion species inhabiting European synanthropic habitats. Externally extremely similar are forms of Arion ater s. 1. (Linnaeus, 1758), a taxon which is widely distributed and common across Western and Central Europe (WIKTOR 1973, ROWSON 2017). It occurs in synanthropic habitats as well as natural ones such as woodland and open grassland (RÜETSCHI et al. 2012, WeLTER-SCHULTES 2012, RowsOn et al. 2014b). As an inhabitant of synanthropic habitats, it has also been spread by human activities, partly even by deliberate introduction (WIKTOR 1973, VON PROSCHWITZ 1997, WIESE 2014). The eastern margin of its natural range is not clear, but it is assumed to lie somewhere in western Poland (WIKTOR 1973, WELTER-SCHUlTES 2012, ROWSON 2017). There are also isolated populations in Eastern Europe such as in Latvia (RUDZīTE et al. 2010) and Russia (LIKHAREV \& WIKTOR 1980), indicating earlier introductions (RowsON 2017). In contrast to A. lusitanicus, $A$. ater s. l. made the step across the Atlantic long ago, occurring in both Canada and the United States (PILSBRY 1948, FORSYTH 2004); more recently it has turned up in Australia (ZEMANOVA et al. 2018).

\section{MATERIAL, METHODS AND RESULTS}

\section{COLLECTION}

Our investigations were initiated by a garden owner in Istanbul (Turkey) inquiring about a heavy slug infestation. We collected a sample of slugs in this garden (site 3 ) and at four additional sites where we noticed further occurrences (Table 1, Fig. 1). Four of the sites were within the European area of Istanbul and had similarly high slug densities. Site 5 was on the Asian side of Istanbul and had a lower slug density.
Here, we report the discovery of $A$. ater s. 1. in Turkey and document that it is already quite widespread in the area of Istanbul.

The taxonomy of $A$. ater s. 1. is somewhat unresolved. It has been disputed whether $A$. ater s. s. should be considered as conspecific with $A$. rufus (Linnaeus, 1758) (the former then representing a subspecies $A$. ater ater from the northern parts of the distribution range), but the two taxa tend to be treated as separate species by current taxonomists. Based on molecular data, Rowson et al. (2014a) recently split A. rufus further into two species, A. rufus s. s. and A. empiricorum. But mitochondrial sequences alone are not sufficient evidence to make species distinctions within a group of taxa known to hybridise (contra PELÁEZ et al. 2018). REISE et al. (2017 and unpublished data) have observed a considerable anatomical variability of this group in Central Europe and recognised three morphological types including one corresponding to A. ater s. s. As taxonomy is not the task of this paper, and in order to avoid having to decide for one or the other name, we decided to use the name $A$. ater s. l., referring to A. rufus s. s., A. empiricorum, A. ater s. s. and potential further (western European) forms.

Table 1. Collection localities and the habitats of the immediate and surrounding areas. $N_{c}-$ number of specimens collected; $N_{\mathrm{d}}$ - number dissected

\begin{tabular}{|c|c|c|c|c|c|}
\hline \multirow{2}{*}{ Site } & \multirow{2}{*}{$\begin{array}{l}\text { Locality, } \\
\text { coordinates }\end{array}$} & \multirow{2}{*}{$N_{\mathrm{c}}$} & \multirow{2}{*}{$N_{\mathrm{d}}$} & \multicolumn{2}{|c|}{ Habitat } \\
\hline & & & & Collection habitat $(0-10 \mathrm{~m})$ & Surrounding habitat (10-200 m) \\
\hline 1 & $\begin{array}{l}\text { Bahçeköy } \\
41^{\circ} 10^{\prime} 31^{\prime \prime N} \\
28^{\circ} 59^{\prime} 32^{\prime \prime} \mathrm{E}\end{array}$ & 20 & 7 & Concrete and stone wall, garden & $\begin{array}{l}\text { Deciduous trees, shrubs, buildings, grass } \\
\text { and weeds }\end{array}$ \\
\hline 2 & $\begin{array}{l}\text { Bahçeköy } \\
41^{\circ} 10^{\prime} 42^{\prime \prime} \mathrm{N} \\
28^{\circ} 59^{\prime} 44^{\prime \prime} \mathrm{E}\end{array}$ & 20 & 7 & $\begin{array}{l}\text { Asphalt road, soil, weeds and grass, } \\
\text { buildings, vegetable garden, deciduous trees }\end{array}$ & $\begin{array}{l}\text { Deciduous trees (Quercus, Fagus, Carpinus), } \\
\text { bushes, edge of forest, buildings, grass and } \\
\text { weeds }\end{array}$ \\
\hline 3 & $\begin{array}{l}\text { Haciosman } \\
41^{\circ} 08^{\prime} 14^{\prime \prime} \mathrm{N} \\
29^{\circ} 01^{\prime} 22^{\prime \prime} \mathrm{E}\end{array}$ & 20 & 8 & Grass and weeds, garden & $\begin{array}{l}\text { Bushes, building, coniferous forest (Pinus), } \\
\text { edge of forest }\end{array}$ \\
\hline 4 & $\begin{array}{l}\text { Zekeriyaköy } \\
41^{\circ} 12^{\prime} 29^{\prime \prime} \mathrm{N} \\
29^{\circ} 02^{\prime} 36^{\prime \prime} \mathrm{E}\end{array}$ & 20 & 5 & Grass, garden, ornamental plants, street & $\begin{array}{l}\text { Fruit trees, vegetable garden, buildings, } \\
\text { coniferous forest (Pinus) and deciduous } \\
\text { trees, residential areas }\end{array}$ \\
\hline 5 & $\begin{array}{c}\text { Elmalı } \\
41^{\circ} 04^{\prime} 29^{\prime \prime} \mathrm{N} \\
29^{\circ} 07^{\prime} 07^{\prime \prime} \mathrm{E}\end{array}$ & 10 & 5 & Soil, grass and weeds & $\begin{array}{l}\text { Buildings, bushes, deciduous trees, } \\
\text { coniferous forest (Pinus), edge of forest }\end{array}$ \\
\hline
\end{tabular}




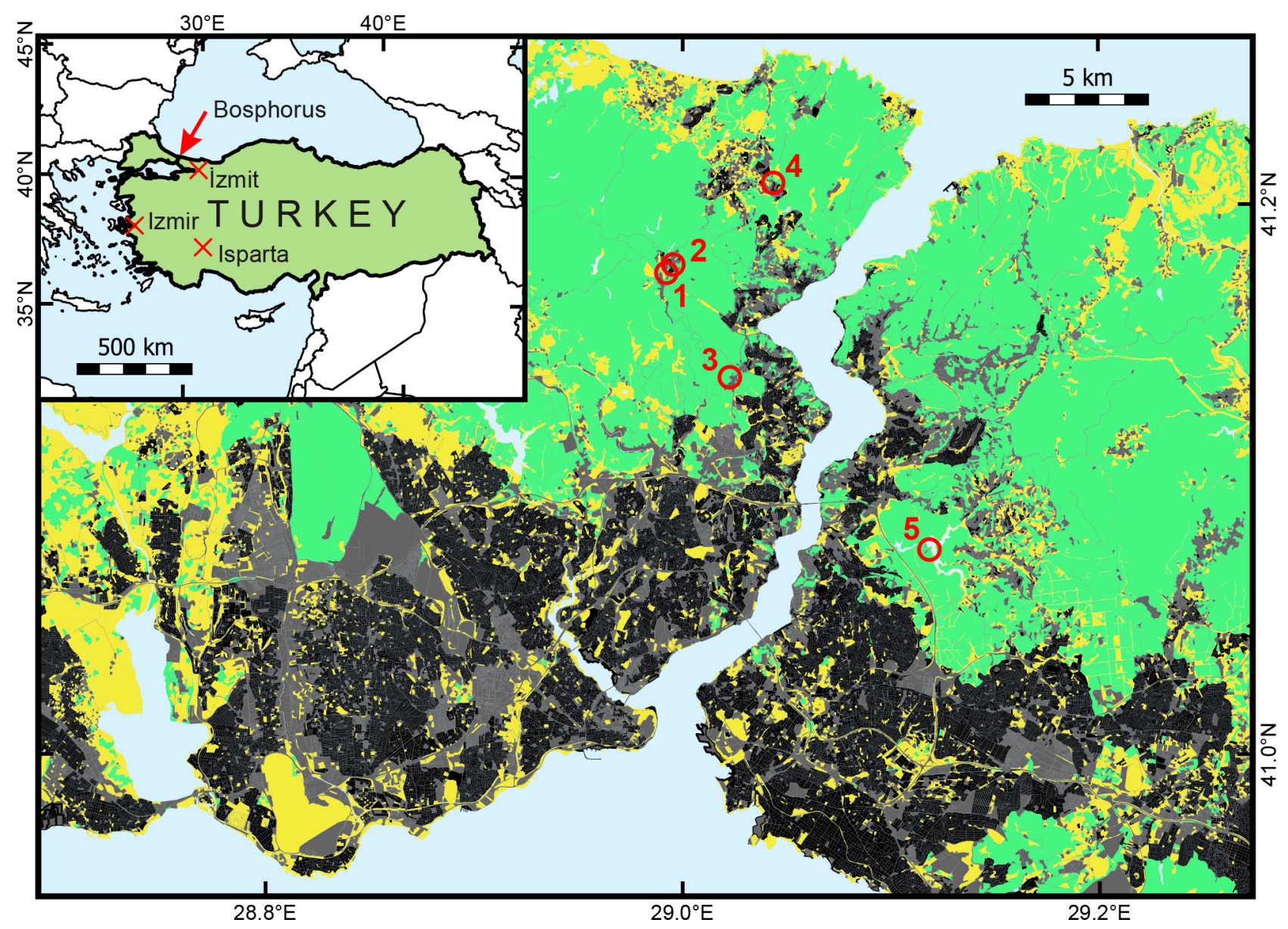

Fig. 1. The inset map of Turkey (green) shows the location of the cities of Isparta, Izmir and İzmit and of the Bosphorus strait between Europe and Asia. The main map shows the Bosphorus with the five numbered sites where we sampled Arion ater s. 1. (numbers according to Table 1). The colour coding of the main map indicates land use: black and grey - built-up areas; green - forest and other more natural habitats; yellow - agricultural land and other disturbed vegetated habitats. Based on data from Natural Earth and the Copernicus Urban Atlas; drawn using QGIS v. 3.2 (QGIS DEVELOPMENT TEAM 2017)

preserved in $75 \%$ ethanol. Seven specimens from sites 1-3 were sent to the Senckenberg Museum of Natural History Görlitz (SMNG), Germany (with permission of the General Directorate of Nature Conservation and National Parks of Turkey).

Thirty-two of the collected specimens were dissected and determined anatomically: five from each of the five localities by $\mathrm{ZA}$, and the seven sent to the SMNG by HR. The specimens in the SMNG are now stored in that collection (numbers p22687-p22689); 25 specimens (5 per site) are in the collection of the Department of Forest Entomology and Protection in the Istanbul University Cerrahpasa (Gastropoda 00001-00005).

\section{MORPHOLOGY}

Living specimens (Figs 2-5) were large, bulky slugs with coarse tubercles on the back and sides. The body colour ranged from orange or reddish to dark brown. One (smaller) specimen from locality 1 showed lateral bands (Fig. 4). The sole fringe was orange to red, the sole light cream. The body length when crawling ranged from 75 to $150 \mathrm{~mm}$.

All dissected specimens were sexually mature or subadult, and the majority showed the typical characters of $A$. ater s. l., as presented in, for instance, ROWSON et al. (2014b) or WIKTOR (1973): the external appearance combined with the bulky, more or less spherical proximal atrium and the small, thin free oviduct (Fig. 6). All the specimens deposited in the SMNG (from localities 1, 2 and 3) are most similar to the ater-form identified by REISE et al. (2017). Relevant characters are the comparatively large lower atrium, the shape of the ligula and its insertion on the inner wall of the proximal atrium.

A few specimens from sites 1, 2, 3 and 5 had some genital characters untypical of $A$. ater s. 1. (HR: unpublished data) but also of $A$. lusitanicus, requiring further investigation. Currently, we consider it possible that these specimens are hybrids between the two species. 

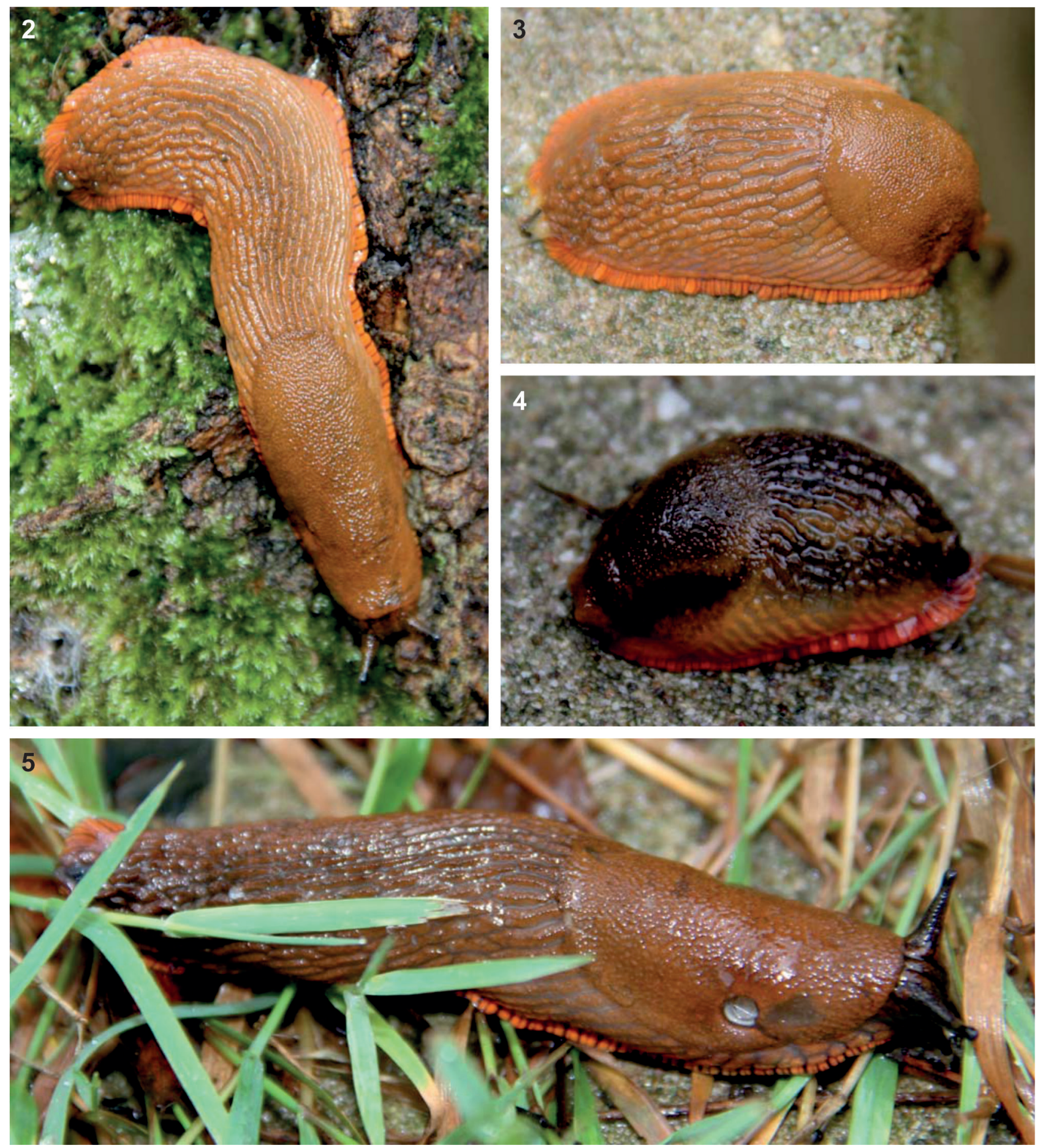

Figs 2-5. External appearance of large Arion from Istanbul (from sites 3, 2, 1 and 3 respectively). Figure 4 shows one of the anatomically untypical specimens mentioned in the text and the only one with lateral bands

\section{MOLECULAR STUDIES}

For three specimens, one from each of sites 1,2 and 3 , we sequenced the standard barcoding region (655 bp) of the mitochondrial COI (cytochrome c oxidase subunit I) gene. Tissue samples were taken from the foot. DNA extraction followed WINNEPENNINCKX et al. (1993). For DNA amplification, we used Taqpolymerase, buffer from Peqlab (Erlangen) and the standard barcoding primers LCO1490 and HCO2198 (FOLMER et al. 1994). PCR was carried out with total volumes of $10 \mu \mathrm{l}, \mathrm{T}_{\mathrm{a}}=40^{\circ} \mathrm{C}, 38$ cycles. The DNA fragments were gel purified with the QiaQuick gel extraction kit (Qiagen, Hilden, Germany) and then sent to the Senckenberg BIK-F Laborzentrum (Frankfurt) for direct sequencing in both directions. The sequencing electropherograms were checked manually. 


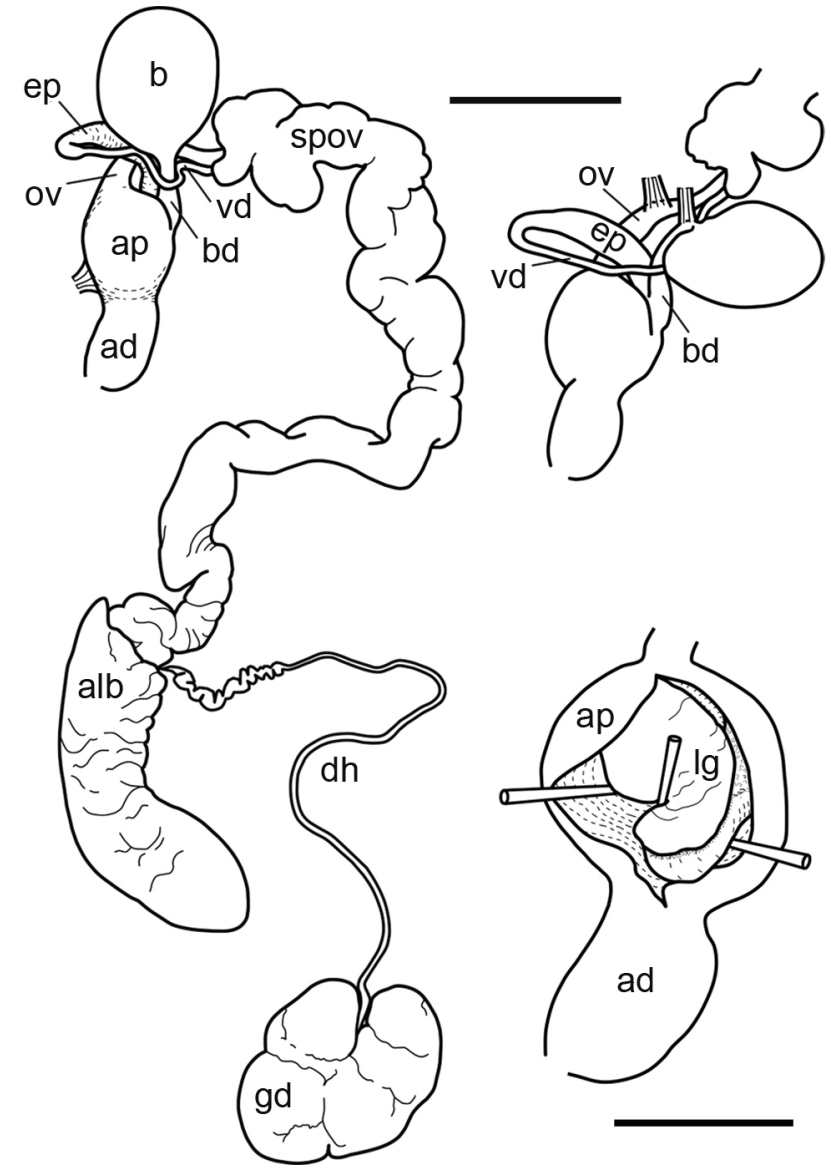

We compared the Istanbul partial-COI haplotype with the hundreds of sequences of large Arion available from Genbank (particularly from the studies of
Fig. 6. Genital anatomy of a typical specimen from site 2 . In the top right-hand drawing, the genitalia have been slightly reorientated to reveal the insertions of epiphallus and bursa duct. The bottom-right drawing, at a higher magnification, shows the proximal atrium opened to reveal the ligula. Abbreviations: ad - distal atrium, ap - proximal atrium, alb - albumen gland, b - bursa, bd bursa duct, dh - ductus hermaphroditicus, ep - epiphallus, gd - gonad, lg - ligula, ov - oviduct, spov - spermoviduct (upper scale bar $10 \mathrm{~mm}$, lower scale bar $5 \mathrm{~mm}$ )

PFENNINGER et al. 2014 and ZEMANOvA et al. 2016) supplemented by our own unpublished sequences. The three individuals from Istanbul were identical with each other (GenBank accession number MH830239), and most similar (differing by 3\%, 18$20 \mathrm{bp}$ ) to a group of three haplotypes (KX834752, KJ842906, KJ842937) from western France, which differed by only 3-5 bp amongst themselves. The first of these is identified as A. vulgaris in GenBank and in Table S5 of the associated publication, ZEMANOVA et al. 2016 (although not in the phylogenetic tree in Fig. S2 of this same paper), but the sequence is very untypical of other $A$. lusitanicus. The other two were deposited as "Arion sp." by PfENNINGER et al. (2014). The next most similar haplotypes to that from Istanbul are considerably more different (9\%) and fall within the clade identified by ZEMANOVA et al. (2016) as A. ater s. s. (e.g. KJ842864, KJ842862, $\mathrm{KJ} 842870)$. Differences from members of the clades that ZEMANOvA et al. (2016) identified as A. rufus and $A$. vulgaris are typically a little higher still (c. $10 \%$ and $11 \%)$.

\section{DISCUSSION}

Our records of $A$. ater s. 1 . constitute the first from Turkey, and locality 5 is the first from Asia. We know of no potential source populations in the close neighbourhood of Turkey. Records from Bulgaria are most likely referring to A. lusitanicus (OSHANOVA 1968, DAMJANOV \& LIKHAREV 1975, IRIKOV \& ERÖSS 2008), and old literature records from Romania, Albania and Bosnia need verification (WIKTOR 1996, PĂPUREANU et al. 2014 and references therein, FEHÉR \& ERÖSS 2009). The southeastern margin of the distribution range of $A$. ater s. 1. and its closest confirmed occurrence to Turkey is considered to be in western Hungary (PINTÉR \& SUARA 2004, ROWSON 2017).

The genital anatomy places our specimens clearly into $A$. ater s. 1 . and excludes A. lusitanicus. However, it is more puzzling where within $A$. ater s. 1 . the Turkish specimens should be placed. The genetic results, based only on a mitochondrial sequence, indicate some distance from forms of $A$. ater s. 1 . commonly found in Central and Northern Europe, Britain and northern Spain, and a closer relationship

to populations from western France. The taxonomic identity of these haplotypes fitting best with our Istanbul haplotype is somewhat uncertain. They were generated by studies concentrating on genetics, but not on morphology. PFENNINGER et al. (2014) do not provide any information on the morphology of their two specimens, and labelled them as "Arion sp.", probably because the sequences could not be assigned to a named species in GenBank. Subsequently a third similar sequence was labelled as A. vulgaris by ZEMANOVA et al. (2016), but it is very different from those of others from this species (= A. lusitanicus).

The taxonomy of large Arion is still somewhat unresolved and requires further research, particularly in Southwest Europe. CHEVALLIER $(1972,1974)$ distinguished four subspecies of $A$. rufus (and separated $A$. ater as its own species), of which two were limited to western parts of France. This was entirely based on morphological characters, but, nevertheless, it indicates the presence of genetically distinct populations in western France. 
The most similar haplotypes besides these three uncertain specimens are from individuals named in Genbank as A. ater s. s., which fits with our morphological determination of the Turkish slugs as closest to the ater-form of $A$. ater s. 1. (REISE et al. 2017). However, the Istanbul slugs' body colour, particularly those bright orange to reddish brown, is very untypical of $A$. ater s. s., which tends to be dark brown or black. The colouration of $A$. ater s. s. does vary over a wider range than this, from whitish yellow to black, but bright orange or red are not mentioned by, for example, Rowson et al. (2014b) or WIESE (2014).

The genus Arion is not native to Turkey (WELTERSCHULTES 2012), and only two species of Arion had been reported from there: A. subfuscus (subgenus Mesarion) from the town of Sapanca, northwestern Turkey, in 2003 (YILDIRIM \& KEBAPÇI 2004) and a single individual of a large Arion (subgenus Arion) determined as $A$. vulgaris (YILDIRIM \& GÜRLEK 2017). The latter was found in 2017 in a pot plant, which had been bought in the city of Isparta (c. $400 \mathrm{~km} \mathrm{SSE}$ of Istanbul, Fig. 1), but, according to the florist who had sold the plant, it originated from the surroundings of Izmir on the west coast (Fig. 1). However, this determination as A. vulgaris (the same species that we term $A$. lusitanicus auct. non Mabille) was based solely on external characters (YILDIRIM \& GÜRLEK 2017, ÜMIT KEBAPÇI pers. comm.). So, in the light of our discovery of several strong populations of $A$. ater s. 1 . in Istanbul, it would be highly desirable to reinvestigate the specimen from Isparta. In addition to this record, already in 2015 a large Arion was photographed in the city of İzmit (c. $100 \mathrm{~km}$ E of our sites, Fig. 1, CARLISLE 2015); the external appearance is compatible with A. ater s. 1. and perhaps A. lusitanicus, but information on genitalia or genetics would be required for a reliable species identification.

A. lusitanicus and A. ater s. 1. both exhibit considerable colour polymorphism, and lighter or darker orange-brown individuals are very common in both taxa. Genital anatomy is thus essential for species determination, but rather straightforward unless hybrids occur: $A$. ater s. 1 . has a large, muscular and more or less spherical proximal genital atrium, and a thin, rather short oviduct (Fig. 6), whereas A. lusitanicus has a comparatively small atrium with a thick, tubular oviduct inserting onto it (see, e.g. Rowson et al. 2014b).

We cannot exclude that $A$. lusitanicus is also present in Istanbul, but at least it seems not to be the predominant species. The fast spread of this conspicuous slug elsewhere has attracted much pub- lic attention, because it can quickly establish populations with very high densities and cause much damage in gardens. It has been classified as one of the 100 worst pest species (RABITSCH 2006). New records of $A$. ater s. 1. outside its native range are rarer and usually not correlated with reports of mass occurrences or considerable damage of garden crops. However, this species has also been assigned a potential as a horticultural pest (GODAN 1979, ROWSON et al. 2014b), and the gardener's complaint from Istanbul confirms this. Interestingly, species distribution modelling by ZEMANOVA et al. (2018) has not classified Turkey as providing suitable climatic conditions for invasion by $A$. lusitanicus or $A$. ater s. 1., neither currently nor within the next 50 years. Possibly the form of $A$. ater s. 1. from Istanbul (and potentially from western France) differs in its climatic tolerance.

The trend of range expansion of $A$. ater s. 1 . is countered by a decline in some Central European and Scandinavian countries caused by its invasive congener A. lusitanicus. Where A. lusitanicus has established strong populations, $A$. ater s. 1 . tends to be replaced in synanthropic habitats within a few years, and then remains restricted to natural habitats (e.g. VON PROSCHWITZ 1997, RÜETSCHI et al. 2012, HATTELAND et al. 2015). One reason for the displacement might be hybridisation between $A$. ater s. l. and A. lusitanicus (REISCHÜTZ \& REISCHÜTZ 2007, RÜETSCHI et al. 2012, DREIJERS et al. 2013, HATTELAND et al. 2013, ZEMANOVA et al. 2017). Morphological intermediates have been observed at sites of co-occurrence (ZEMANOVA et al. 2017, REISE et al. unpublished). The few morphologically untypical individuals amongst the Istanbul specimens might indicate the presence of $A$. lusitanicus. Another indication is the body colouration of the mature or subadult slug depicted in Fig. 4 and belonging to those untypical individuals: the banded pattern resembles that of juvenile or subadult A. lusitanicus rather than of typical A. ater s. 1., although the latter can also be banded (Rowson et al. 2014b). It will be worthwhile to keep the population of $A$. ater s. 1. in Istanbul under observation over the next few years.

\section{ACKNOWLEDGEMENTS}

We thank ALI GÜNDOĞDU for helping to process the slug samples in the laboratory and ÜMIT KEBAPÇI for information about the record of Arion lusitanicus (= A. vulgaris) from Isparta. We also thank the three anonymous referees and ANDRZEJ LESICKI for their comments on the text. 


\section{REFERENCES}

BALASHOV I. 2018. Case 3685 - Arion vulgaris MoquinTandon, 1855 (Gastropoda, Stylommatophora, Arionidae): proposed validation of the specific name as available. Bulletin of Zoological Nomenclature 75: 12-15. https://doi.org/10.21805/bzn.v75.a006

CARlisle T. R. 2015. Chocolate Arion (Arion rufus). Available online at https://www.inaturalist.org/ observations/2342095 (accessed 12 November 2018).

Chevallier H. 1972. Arionidae (Mollusca, Pulmonata) des Alpes et du Jura français. Haliotis 2: 7-23.

Chevallier H. 1974. Les grands Arion de France (Mollusca, Pulmonata). Taxonomie, biogeographie, écologie, polymorphisme, croissance et cycle biologique. Doctoral thesis, Université de Paris.

DAMJANOV S. G., LiKHAREV I. M. 1975. Fauna na B'lgarija. 4. Gastropoda terrestria. Bulgarian Academy of Sciences, Sofia.

Dreijers E., Reise H., Hutchinson J. M. C. 2013. Mating of the slugs Arion lusitanicus auct. non Mabille and $A$. rufus (L.): different genitalia and mating behaviours are incomplete barriers to interspecific sperm exchange. Journal of Molluscan Studies 79: 51-63. https://doi. org/10.1093/mollus/eys033

FEHÉR Z., ERÖSS Z. P. 2009. Checklist of the Albanian mollusc fauna. Schriften zur Malakozoologie 25: 22-38.

Folmer O., Black M., HOEH W., LUTZ R., VRIJENHOEK R. 1994. DNA primers for amplification of mitochondrial cytochrome $\mathrm{c}$ oxidase subunit I from diverse metazoan invertebrates. Molecular Marine Biology and Biotechnology 3: 294-299.

Forsyth R. G. 2004. Royal BC Museum handbook: land snails of British Columbia. Royal BC Museum, Victoria, Canada.

GODAN D. 1979. Schadschnecken und ihre Bekämpfung. Ulmer, Stuttgart.

HATTEland B. A., Roth S., ANDERSEN A., KAASA K., STøA B., SOLHØY T. 2013. Distribution and spread of the invasive slug Arion vulgaris Moquin-Tandon in Norway. Fauna norvegica 32: 13-26.

Hatteland B. A., SOlhøy T., Schander C., SkAge M., VON PROSCHWITZ T., NOBLE L. R. 2015. Introgression and differentiation of the invasive slug Arion vulgaris from native A. ater. Malacologia 58: 303-321. https:// doi.org/10.4002/040.058.0210

IRIKOV A., ERÖSS Z. 2008. An updated and annotated checklist of Bulgarian terrestrial gastropods (Mollusca: Gastropoda). Folia Malacologica 16: 197-205. https:// doi.org/10.12657/folmal.016.015

LIKHAREV I. M., WIKTOR A. J. 1980. Slizni fauny SSSR i sopredelnykh stran (Gastropoda terrestria nuda). Fauna SSSR (Novaja serija 122) 3 (5): 1-437. Academy of Sciences, Zoological Institute, Leningrad.

OsHANOVA N. 1968. Zur Verbreitung der Arionidae in Bulgarien (Gastropoda). Malakologische Abhandlungen Staatliches Museum für Tierkunde Dresden 2: 235-241.

PĂPUREANU A.-M., REISE H., VARGA A. 2014. First records of the invasive slug Arion lusitanicus auct. non Mabille (Gastropoda: Pulmonata: Arionidae) in Romania.
Malacologica Bohemoslovaca 13: 6-11. http://mollusca. sav.sk/pdf/13/13.Papureanu.pdf

Peláez M. L., Valdecasas A. G., Martinez D., Horreo J. L. 2018. Towards the unravelling of the slug A. ater-A. rufus complex (Gastropoda Arionidae): new genetic approaches. Web Ecology 18: 115-119. https:// doi.org/10.5194/we-18-115-2018

PfEnNinger M., Weigand A., BÁlint M., KlussmanNKolB A. 2014. Misperceived invasion: the Lusitanian slug (Arion lusitanicus auct. non-Mabille or Arion vulgaris Moquin-Tandon 1855) is native to Central Europe. Evolutionary Applications 7: 702-713. https://doi. org/10.1111/eva.12177

PILSBRY H. A. 1948. Land Mollusca of North America (north of Mexico). Vol. II, Part 2. Academy of Natural Sciences of Philadelphia, Philadelphia, i-xlvii, 521-1113.

PINTÉR L., SUARA R. 2004. A magyarországi puhatestűek elterjedése II. Hungarian Museum of Natural History, Budapest.

QGIS DEVELOPMENT TEAM 2017. QGIS Geographic Information System. Open Source Geospatial Foundation Project. Available online at https://www.osgeo. org/projects/qgis/ (accessed 2017).

RABITSCH W. 2006. DAISIE Arion vulgaris (Moquin-Tandon, 1855) Fact Sheet. Online Database of Delivering Alien Invasive Species Inventories for Europe. Available online at http://www.europe-aliens.org/speciesTheWorst.do (accessed 05 November 2018).

REISCHÜTZ A., REISCHÜTZ P. L. 2007. Rote Liste der Weichtiere (Mollusca) Österreichs. In: ZULKA K. P. (ed.). Rote Listen gefährdeter Tiere Österreichs. Teil 2: Kriechtiere, Lurche, Fische, Nachtfalter, Weichtiere. Grüne Reihe des Lebensministeriums 14/2: 363-433.

REISE H., SCHWARZER A.-K., HutChinson J. M. C., SCHLITT B. 2017. Co-occurrence and hybridisation of three morphotypes of Arion rufus and A. ater in Eastern Saxony, Germany. In: ĆMIEL A. M., LIPIŃSKA A., ZAJĄC K., ZAJĄC T., CAMERON R. A. D. (eds): EUROMAL, 8th European Congress of Malacological Societies, 10-14 September 2017, Kraków, Poland, Book of Abstracts, Bogucki Wydawnictwo Naukowe: 82.

RowsON B. 2017. Arion rufus. The IUCN Red List of Threatened Species 2017: e.T171016A1320066.

ROWSON B., ANDERSON R., TURNER J. A., SYMONDSON W. O. C. 2014a. The slugs of Britain and Ireland: undetected and undescribed species increase a well-studied, economically important fauna by more than $20 \%$. PLoS ONE. 9: e91907. https://doi.org/10.1371/journal. pone.0091907

ROWSON B., TURNER J., ANDERSON R., SYMONDSON B. 2014b. Slugs of Britain and Ireland. Identification, understanding and control. Field Studies Council, Telford /National Museum of Wales, Cardiff.

Rudzīte M., Dreijers E., Ozolina-Moll L., Parele E., PILĀTE D., RudZītis M., STALAŽS A. 2010. Latvijas gliemji: sugu noteicējs. A guide to the molluscs of Latvia. LU Akadēmiskais apgāds, Rīga.

RÜETSCHI J., STUCKI P., MÜLLER P., VICENTINI H., ClAUdE F. 2012. Rote Liste Weichtiere (Schnecken und 
Muscheln). Gefährdete Arten der Schweiz, Stand 2010. Bundesamt für Umwelt, Bern und Schweizer Zentrum für die Kartographie der Fauna, Neuenburg. UmweltVollzug Nr. 1216. https://www.bafu.admin.ch/bafu/ de/home/themen/biodiversitaet/publikationen-studien/publikationen/rote-liste-weichtiere.html

VON Proschwitz T. 1997. Arion lusitanicus Mabille and A. rufus (L.) in Sweden: a comparison of occurrence, spread and naturalization of two alien slug species. Heldia 4: 137-138.

WELTER-SCHULTES F. W. 2012. European non-marine molluscs, a guide for species identification. Planet Poster Editions, Göttingen.

WIESE V. 2014. Die Landschnecken Deutschlands. Quelle \& Meyer, Wiebelsheim.

WIKTOR A. 1973. Die Nacktschnecken Polens. Arionidae, Milacidae, Limacidae (Gastropoda, Stylommatophora). Monografie Fauny Polski 1. Polish Academy of Sciences, Warsaw, Krakow.

WIKTOR A. 1996. The slugs of the former Yugoslavia (Gastropoda terrestia nuda - Arionidae, Milacidae, Limacidae, Agriolimacidae). Annales Zoologici 46: 1-110. http://rcin.org.pl/dlibra/docmetadata?id=57707

WINNEPENNINCKX B., BACKELJAU T., DE WACHTER R. 1993. Extraction of high molecular weight DNA from molluscs. Trends in Genetics 9: 407. https://doi. org/10.1016/0168-9525(93)90102-N
YILDIRIM M. Z., GÜRLEK M. E. 2017. Türkiye Karasal Gastropod Faunası için Yeni Kayıt: Arion vulgaris Moquin-Tandon 1855 (Gastropoda: Pulmonata: Arionidae). Mehmet Akif Ersoy Üniversitesi Fen Bilimleri Enstitüsü Dergisi 8 (Ek Sayı 1): 228-230.

YILDIRIM M. Z., KEBAPÇı Ü. 2004. Arion (Mesarion) subfuscus (Draparnaud, 1805) a new record of the malacofauna of Turkey. Israel Journal of Zoology 49: 318-319.

Zemanova M. A., KNOP E., HeCKel G. 2016. Phylogeographic past and invasive presence of Arion pest slugs in Europe. Molecular Ecology 25: 57475764. https://doi.org/10.1111/mec.13860

Zemanova M. A., KNOP E., HECKEL G. 2017. Introgressive replacement of natives by invading Arion pest slugs. Scientific Reports 7: 14908. https://doi.org/10.1038/ s41598-017-14619-y

Zemanova M. A., Broennimann O., Guisan A., KNOP E., HeCKel G. 2018. Slimy invasion: climate niche and current and future biogeography of Arion slug invaders. Diversity and Distributions 24: 1627-1640. https:// doi.org/10.1111/ddi.12789

Received: September 9th, 2017

Revised: November 8th, 2018

Accepted: November 12th, 2018

Published on-line: December 11th, 2018 